\title{
The oil and ozokerite mine in Boryslav and historical monuments of petroleum and salt industries in the vicinity of Boryslav (Ukrainian Fore-Carpathian region)
}

Kopalnia ropy naftowej i wosku ziemnego w Borysławiu oraz pamiątki przemysłu naftowego i solnego w okolicy Borysławia (ukraińskie Podkarpacie)

\author{
Andrzej B. Radwański \\ The Museum of Folk Architecture in Sanok, Traugutt Street 3, 38-500 Sanok, \\ present address: The Administrative District in Sanok, e-mail: aradwanski@powiat-sanok.pl \\ The Society of Tourist Guides "Karpaty”, Rynek Street 1, 38-500 Sanok, e-mail: tatry53@op.pl
}
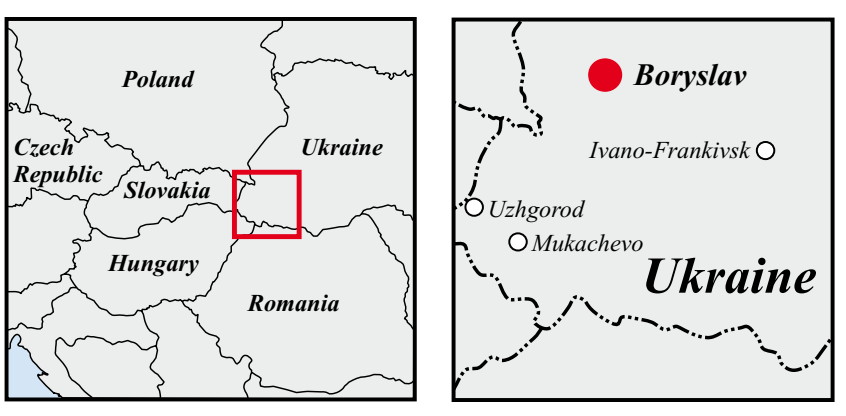

\begin{abstract}
The Boryslav region was one of the world largest petroleum basins, discovered in the second half of the 19th century. Situated southwest from Drohobych, it includes several localities: Boryslav - Tustanovychi - Mraznytsa - Banya Kotyvska with their rich and long history of brine and salt industry dating back to the 12th century. Rapid development of mining activity has commenced with the implementation of the new, Canadian method of drilling for oil by the Canadian MacGarvey Company. The decisive date in the activity of the MacGarvey Company was 1893 when exploration drilling for oil commenced in Boryslav and then, in 1895, in Tustanovychi. Discovery of an oilfield in Boryslav was the beginning of the "golden age" of the oil industry in the Fore-Carpathian region and many people amassed fortunes. From the geological point of view, the Boryslav region covers the three Carpathian structural units: Skyba (Skole), Boryslav-Pokuttya and Sambir (Stebnik). The Boryslav-Pokuttya Unit is the main oil reservoir in the Ukrainian Carpathians with multi-layered oilfields, including the largest one - Boryslav. In this region ozokerite deposits are also known, hosted in the salt-bearing Lower Miocene Vorotyscha Beds. The city of Drohobych has become famous for its long tradition of salt trade. In the 19th century the period of rapid development started when the oil industry flourished in the vicinity, although the town was still in the shadow of Boryslav. The city of Truskavets, the famous health resort, has several mineral waters, also related to the oilfields, including the famous "Naftusia" spring. Another interesting site is Urych - the place where patients from the Truskavets resort travelled in order to admire scenic crags of the Yamna Sandstones and ruins of the Tustan Castle. The region of Boryslav and its surroundings was the site of the most effective petroleum exploitation in the territory of Poland in the past. This place is connected with the activity of Stanisław Szczepanowski (1846-1900), pioneer of oil industry and industrialization of the Galicia province.
\end{abstract}

Key words: Boryslav, geotourist trail, Truskavets, Drohobych, ozokerite, Naftusia mineral water, the Skole Beskid, the Ukrainian Carpathians
Treść: Rejon Borysławia, w którym pierwsze złoże odkryto pod koniec XIX wieku, stat się $w$ owym czasie jednym z największych zagłębi naftowych na świecie. Jest on położony na SW od Drohobycza i obejmuje miejscowości Borystaw - TustanowiceMraźnica-Bania Kotowska, o bogatej i dlugiej historii zwiazanej z istniejacym tu od XII w. przemystem solnym. Rozwój działalności wydobywczej wiqże się z wprowadzeniem przez Kanadyjczyka Williama MacGarvey'a metody kanadyjskiej wiercenia otworów poszukiwawczych ropy naftowej. Przetomowa data byt rok 1893, kiedy rozpoczat on wiercenia w Borysławiu, a następnie, $w$ roku 1895, w Tustanowicach. Odkrycie złoża ropy naftowej w Borystawiu zapoczatkowato ,zloty wiek” podkarpackiego przemystu naftowego, a jego odkrywcom zapewniło fortune. Pod względem geologicznym rejon Borysławia położony jest na obszarze występowania trzech karpackich jednostek strukturalnych: skibowej (ukrainska nazwa jednostki skolskiej), borysławsko-pokuckiej i samborskiej (ukraińska nazwa jednostki stebnickiej). Jednostka borystawsko-pokucka jest podstawowa strukturq roponośna $w$ Karpatach ukraińskich, $w$ której uformowaty się wielohoryzontowe złoża ropy naftowej, w tym największe z nich-Borysław. Mamy tu złoża ozokerytu w mioceńskich, solonośnych warstwach worotyszczańskich. Drohobycz, miasto przez wieki zyjace z handlu sola, $w$ XIX wieku zaczą gwattownie rozwijać się $w$ cieniu Borystawia, stajac sie zapleczem dla przemystu naftowego. Truskawiec to wielkie uzdrowisko, posiadajace wiele wód mineralnych, towarzyszacych złożom ropy naftowej, w tym stynnq „Naftusię”. Innym interesujacym miejscem jest Urycz miejscowość, do której wyjeżdzali kuracjusze wypoczywajacy w Truskawcu by podziwiać piękne ostańce skalne (piaskowce jamneńskie) oraz ruiny zamku Tustań. Borystaw i jego okolice byt w tych czasach największym obszarem naftowym na ziemiach polskich. Z miejscem tym jest zwiqzana działalność Stanisława Szczepanowskiego (1846-1900), pioniera przemystu naftowego i rzecznika uprzemystowienia Galicji.

Słowa kluczowe: Borysław, szlak geoturystyczny, Truskawiec, Drohobycz, ozokeryt, ropa naftowa, woda mineralna Naftusia, Beskidy Skolskie, Karpaty ukrainskie

\section{Introduction}

In the geographical subdivision Boryslav is situated at the external, northern margin of the Carpathian arc, in the foreland of the Beskidy Mts. (Kondracki, 1978), at the confluence of the Ratochyna and Tysmenytsa rivers. The Tysmenytsa River is the right-bank tributary of the Bystrytsa River, which in turn, is tributary of the Dnister River (Fig. 1). 

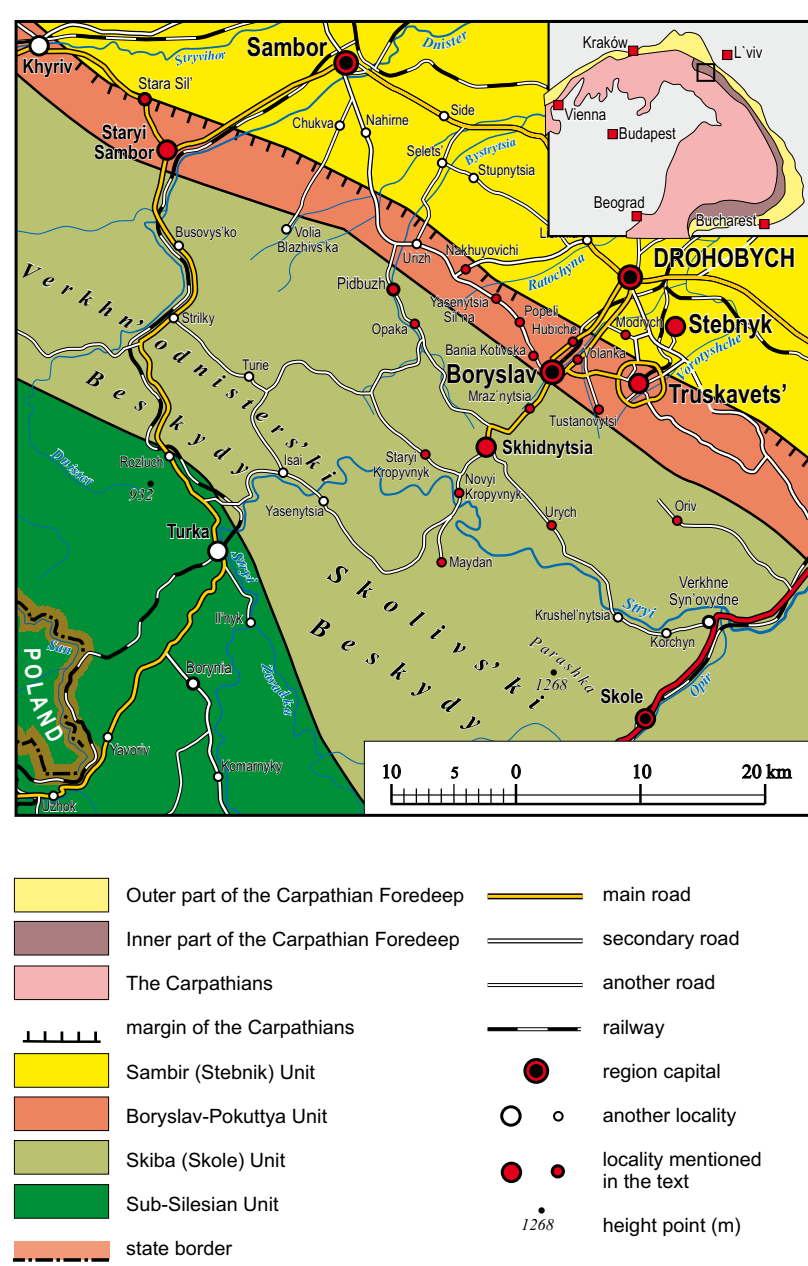

Fig. 1. Geological sketch map, after Kotarba (2009), over the topographical map of the surroundings of Boryslav, after Krukar (2004) - Szkic geologiczny wg Kotarby (2009) na tle mapy topograficznej okolic Borysławia, wg Krukara (2004)

The Boryslav region is one of the oldest petroleum basins in the world. Oil fields with natural gas were discovered in the second half of the 19th century, near the Boryslav-TustanovychiMraznytsa-Banya Kotyvska road (Jawor \& Kruczek, 1994). Moreover, in the vicinity ozokerite (popular name - "earth wax") was mined (Fig. 2). Before the discovery of rich oil fields, Boryslav and Tustanovychi (with nearby Ponerla and Volyanka) were neighboring villages located southwest of Drohobych, the beginnings of which date back to the 14th century (Lenartowicz, 1998).

For small, mountain villages the discovery of oilfields was like entering the new epoch. The view of Boryslav oil district from the time before World War II was presented by Gasiorowski (1935). He wrote: "Boryslav the Great.... This is an area $4 \mathrm{~km}$ wide (along Banya Kotyvska - Boryslav - Tustanovychi line) and $6 \mathrm{~km}$ long (along Boryslav - Mraznytsa line), covered by drilling rigs, triplex pumps and by smaller or larger oil tanks. In total, about 1,000 wells were completed, in which 400 producing ones...”. In 1930 the quickly growing Great Boryslav incorporated the surrounding villages: Tustanovychi, Volyanka, Mraznytsa, Banya Kotyvska and Gubychi.

The Boryslav region is a very important element of the planned Starunia (Ukraine) - Kraków (Poland) trans-border geotourist trail named "Traces of large extinct mammals, earth wax, oil and salt" (Kotarba, 2009).

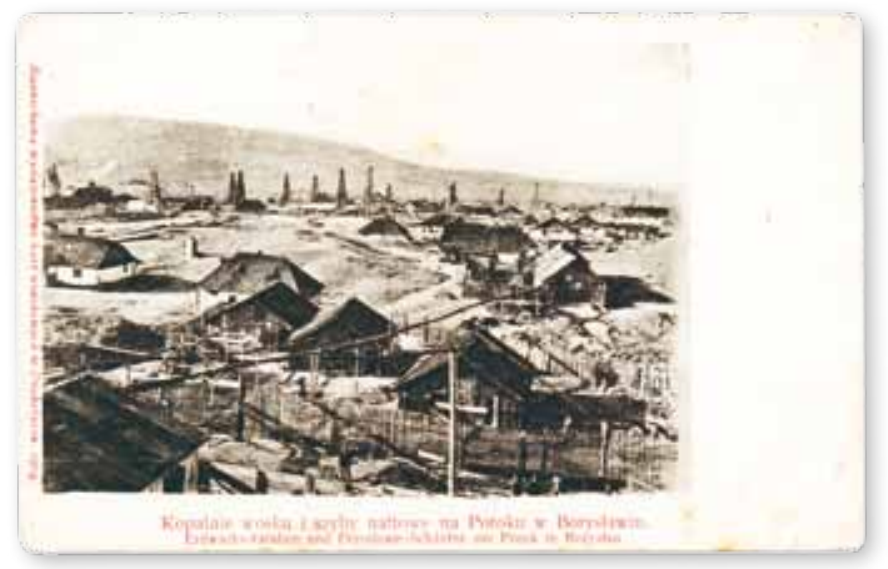

Fig. 2. Ozokerite mine and oil shafts at Potok, a part of Boryslav oil and ozokerite field. Postcard edited in 1904 - Kopalnia ozokerytu i szyby naftowe na Potoku, część pola roponośnego i ozokerytowego Borysław. Pocztówka wydana w 1904 r

\section{Brief history of discovery of Boryslav oil and ozokerite field}

The second half of the 19th century was the time of rapid economic development of the Fore-Carpathian region. The "rock oil", known and used by the local population for many years, soon became the source of wealth. The refined fuel obtained by distillation of "rock oil" made for the first time by Ignacy Łukasiewicz together with Jan Zeh at the "Golden Star" pharmacy in Lviv, and the construction of a new oil lamp provided opportunities for modern illumination, much better than traditional candles. The lamp was constructed by Adam Bratkowski, a tinsmith from Lviv, according to ideas and instructions given by Ignacy Lukasiewicz. Such lamps were used for the first time in the public hospital in Lviv, at night of July 31, 1853, during the urgent surgery which saved life of local proprietor Władysław Cholecki (Sozański, ed., 1996). Since that event, "oil fever" commenced in the Fore-Carpathian region. At the beginning, the oil industry did not generate large profits. The evolution from a homemade activity to industrial operations took quite a long time. However, the quickly growing demand for new lamps and new fuel, and the interest of western investors in exploitation of oil transformed the agricultural Fore-Carpathian region into the oil district. Mining activity has included the vast area from Gorlice in the west to Sloboda in the east. First excavations from which oil was produced were "cellars" dug wells - small, shallow shafts equipped with windlass and pail. The "cellars" were accompanied by shallow, hand drillings. However, progress in recovering oil was very fast. After the first cellar named "Wojciech" was sunk in 1855 under supervision of Ignacy Łukasiewicz in the area of the future Bóbrka oilfield, only thirty years have passed when the first, fully mechanized percussion drilling with the Canadian method was completed. The implementation of new drilling techniques in the Fore-Carpathian region is the merit of William MacGarvey, a Canadian who arrived to Galicia in 1883 at the invitation of Stanisław Szczepanowski, the Polish pioneer of oil exploitation. Since that moment the 


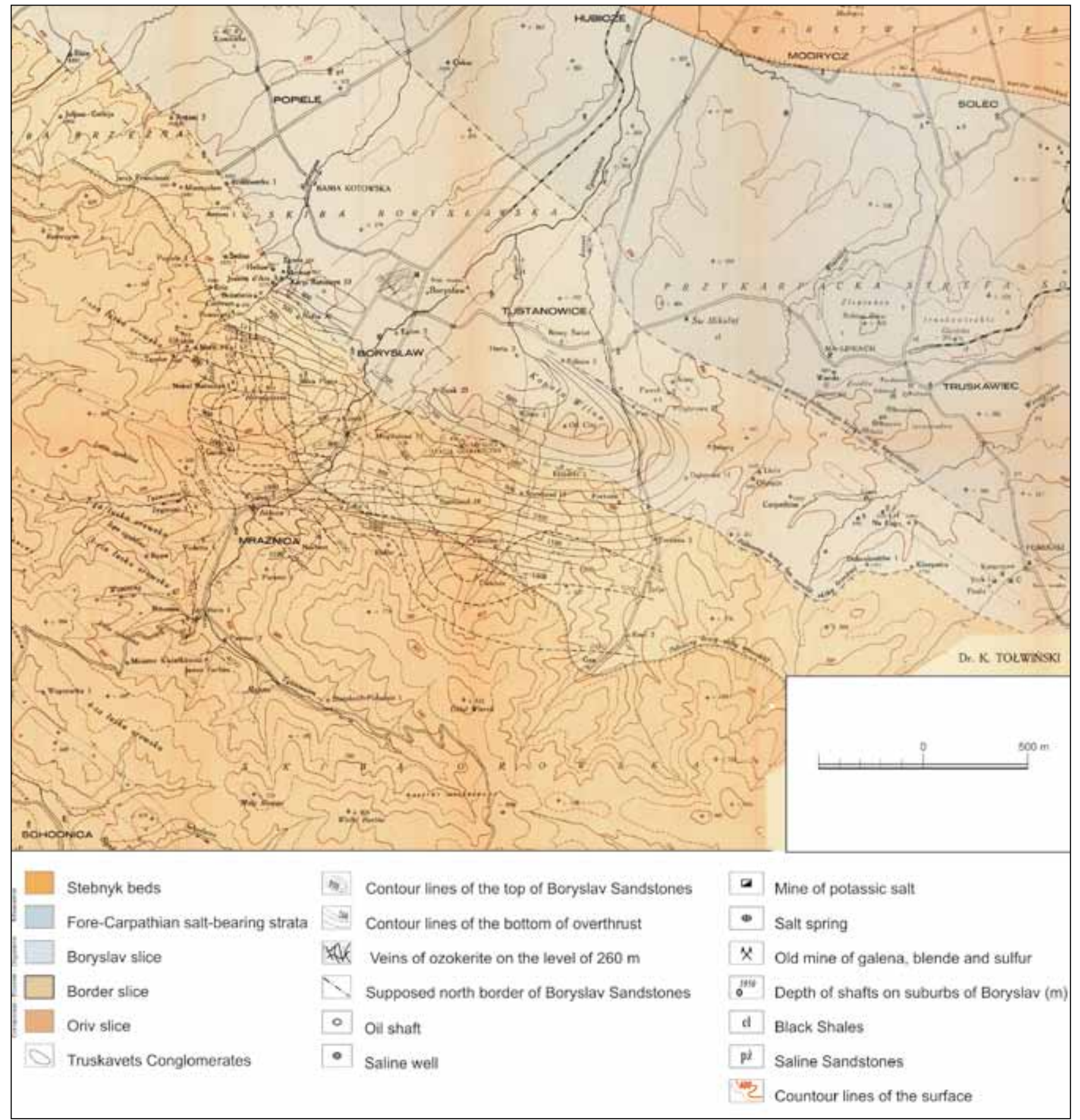

Fig. 3. Geological map of the Boryslav vicinity, after Tołwiński (1937) • Mapa geologiczna okolic Borysławia, według Tołwińskiego (1937)

landscape of the Fore-Carpathian region gained new elements - huge, wooden oil rigs, which number grew very quickly (Orłowicz, 1919; Jawor \& Kruczek, 1994; Michalewicz et al., 2004; Strojny et al., 2005).

The new impuls for the petroleum industry was the construction of the first petrol-combusting piston engine in 187879 by Karl Benz. It was followed by invention of the internal combustion engine by Rudolf Diesel in 1893 (Rychter \& Teodorczyk, 2009).

The decisive date in the activity of MacGarvey was the year 1893, when he has started exploration drilling for oil in Boryslav. At the beginning the results were negative and MacGarvey was almost ready to quit. However, his Polish employee, Władysław Długosz persuaded him to continue drilling and the result of his activity was the discovery of an unusually productive oilfield at 900 metres depth (Nater \& Sozański, 2002). In 1895 MacGarvey started drilling in Tustanovychi. At the same year four Polish investors: Męciński, Płocki, Sroczyński and Suszycki joined him in the oil business. In 1897 there were already 7 oil companies active in the oil business, producing 464 tankers of oil per year (1 tanker $=10$ metric tons). In Tustanovychi the most effective production wells were completed, e.g. famous "Nafta 2" well, which yielded totally 26,500 tankers of oil in the years 1907-1935 (Jawor \& Kruczek, 1994).

Discovery of the oilfield in Boryslav was the beginning of the "golden age" of petroleum industry and was the source of fortunes for many people (Orłowicz, 1919). 


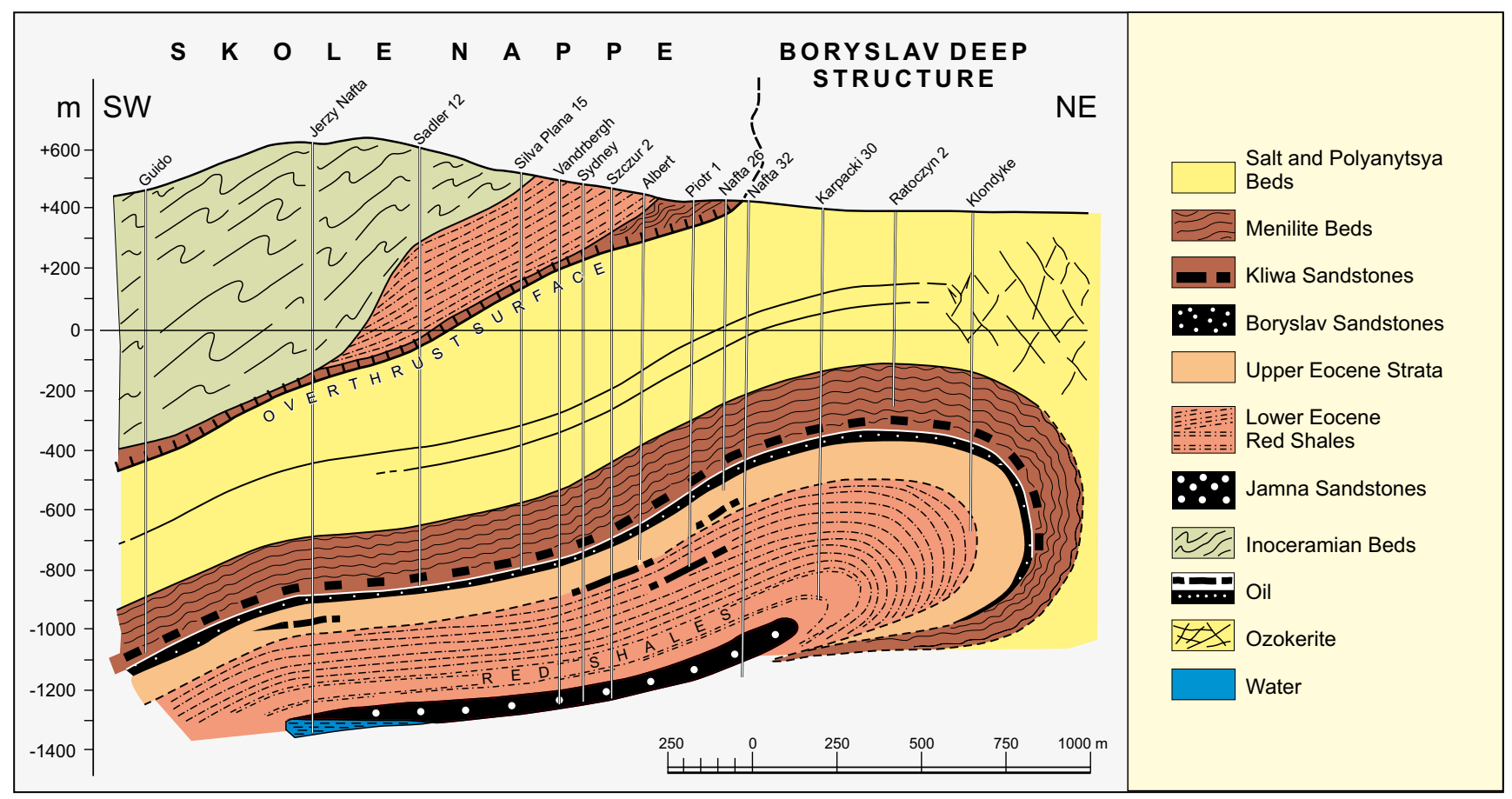

Fig. 4. Geological cross-section through the Boryslav oil field, after Tołwiński (1937) • Przekrój przez złoże ropy naftowej Borysław, według Tołwińskiego (1937)

Władysław Długosz, petroleum industrialist, said: “...during the times of Lukasiewicz, production of mines was quoted in gallons (1 gallon =3,844 litres), after discovery of oilfield in Sloboda it was quoted in barrels ( 1 barrel = about $150 \mathrm{~kg}$ ) but after discovery of oilfields in Boryslav and Skhidnytsa it was reported in railway tankers..." (Nater \& Sozański, 2002). Gąsiorowski (1935) wrote: "The deepest shaft in Boryslav and also in Europe is "Sieghardt 1", which is 1,821 metres deep. The highest shaft is "Statenland" (American system), which is 52 metres tall. The production of oil amounts to 75$90 \%$ of the entire production of Poland".

Discovery of oil fields in the region of Boryslav caused demand for oil storage, transport and processing plants ("distilleries"). Hence, tanks and refineries were built and railway connections were extended (Orliński et al., 2004). The oil exploration and developing works were continued in the Boryslav area and were commenced in other parts of the Fore-Carpathian region. Galicia attracted investors from Austria, Germany, England, Belgium, France, Italy and even from the USA. Soon, branches of western oil concerns were established. It was the beginning of great industrialization in the Fore-Carpathian region. The result was an employment boom for residents of Galicia. It was estimated that every third citizen of this province was working for the oil industry (Nater \& Sozański, 2002).

\section{Outline of geology}

The region of Boryslav covers the area of three Carpathian structural units (Fig. 1). From the southwest to the northeast these are: Skyba (in Poland it is called the Skole Unit), Boryslav-Pokuttya and Sambir (in Poland Stebnik) units (e.g., Wyszniakow et al., 2004a).

The Boryslav-Pokuttya Unit is the main oil-bearing megastructure in the Ukrainian Carpathians. It comprises seve- ral slice-folds, which host multi-layer oilfields, the largest of them being the Boryslav deposit. This unit also hosts several other, important fields: Bytkiv-Babche, Dolyna, Ripne, Skhidnytsa and Sloboda (Jawor \& Kruczek, 1994; Jawor, 2004; Wyszniakow et al., 2004a, 2004b).

Geological structure and oil and gas fields in Boryslav were described in detail by many Polish geologists: K. Tołwiński, J. Grzybowski, P. Kropaczek, R. Zuber and others (fide Jawor \& Kruczek, 1994). According to Tołwiński (1937), the forefront of the Carpathian overthrust in the region of Boryslav includes four slice-folds. From the southwest to the northeast these are: Skole, Oriv, Marginal and Boryslav. Tołwiński (op. cit.) also mentioned four lower-rank elements in the Oriv slice-fold - the slices No. 1 to No. 4, which are separated by synclines numbered from 1 to 3 (Fig. 3). The oil fields in the Great Boryslav area (Boryslav - Banya Kotyvska - Mraznytsa-Tustanovychi) are reservoired in the Boryslav, Marginal and Oriv slice-folds. An interesting fact connected with the oilfields in Boryslav is that oil-bearing structures are covered by a marginal nappe, which does not accumulate petroleum (Fig. 4). Reservoir rocks of the Boryslav oilfield are sandstones ranging from the Upper Cretaceous Stryi Beds to the salt-bearing Miocene Vorotyshcha Beds (Koltun et al., 2005), as shown in the lithostratigraphic column of the BoryslavPokuttya Unit (Fig. 5). The Vorotyshcha Beds include sandstone-claystone breccias cemented with halite, dark-grey clays, mudstones and seams of potassium salt (Korin, 2005).

This deep-seated oil-bearing structure does not crop out at the surface and cannot be explored with classic geological mapping. It is obvious that Boryslav oilfield could not be discovered for a long time without a desperate decision made in 1893 by Władysław Długosz, drilling manager of the MacGarvey, who insisted on continuing drilling of negative wells (Pabis, 2003). 
The Miocene salt-bearing Vorotyshcha Beds reveal one more special feature - these are the host of ozokerite veins and layers. Ozokerite is a geological rarity on a world scale. It was discovered in 1855 in Boryslav. Most of its deposits are located in the Ukrainian Carpathians: Boryslav, Volyanka, Truskavets-Pomiarki, Dzvyniach and Starunia (Bojko \& Sozański, 2004; Alexandrowicz, 2005). Industrial mining of ozokerite dates back to the year 1860 .

Ozokerite is a natural mixture of solid hydrocarbons of black, brown, yellow-brown, sometimes yellow or greenish colors. When touched, it resembles wax, from which its name "earth wax" originates. Ozokerite was formed as the result of rapid degassing and oxidation of petroleum during its migration to the surface. It occurs in sedimentary rocks as the fillings of cracks and caverns. From ozokerite ceresine is obtained, which is a mixture of solid paraffins from $\mathrm{C}_{37} \mathrm{H}_{76}$ to $\mathrm{C}_{53} \mathrm{H}_{108}$ (Bolewski \& Turnau-Morawska, 1963; Kachlik, 1994; Bojko \& Sozański, 2004).

In the past ozokerite played an economically important role in the Galicia province. Ceresine was used in production of candles, grease as well as in the pharmacy and electrical industry. For example, ceresine-derived substances from the Fore-Carpathian region were used in insulation of transatlantic cable connecting Europe and North America (Nater \& Sozański, 2002; Bojko \& Sozański, 2004).

\section{Geoturist objects}

Recently, Boryslav does not resemble an oil district, as it was many years ago. Although the exploitation of petroleum still proceeds, the landscape is not dominated by oil rigs and other industrial objects, like these shown in old photographs and postcards (Sozański, 2004). Present exploitation is run with beam pumps, but tourists must know where to look for them (Fig. 6). It is possible to see two large beam pumps in the southern part of the town (Mraznytsa) near the road to Skhidnytsa. There are still some oil tanks, which have survived two world wars until present day and also additional railway siding, which was used to dispatch oil tankers. Ozokerite was exploited was by underground methods using small shafts (Kachlik, 1994) (Fig. 7). In the old part of Boryslav one can see shaft of the ozokerite mine, currently under closure (Fig. 8). The ozokerite mine in Boryslav has not been operating for 10 years, however, a feasibility study for reconstruction of this mine and plans for its renovation were made (Y.V. Koltun, private comuncation). A relic of the past is the site in Tustanovychi commemorating the tragic fire of the "Oil City" well from 1908. During the drilling of an exploration well an enormous oil eruption took place, yielding about 2,500 metric tons of oil per day (Fig. 9). The fire was set by a lightning strike and its extinguishing took three weeks (Michalewicz et al., 2004; Orliński et al., 2004).

The main tourist attractions of Boryslav are monuments of petroleum industrial heritage. The most important of them are: shaft of ozokerite mine, periodically active only a few years ago and the exhibition of the Museum of Oil Industry (Gąsiorowski, 1935; Sikorska et al., 2005, 2006; Strojny et al., 2005).

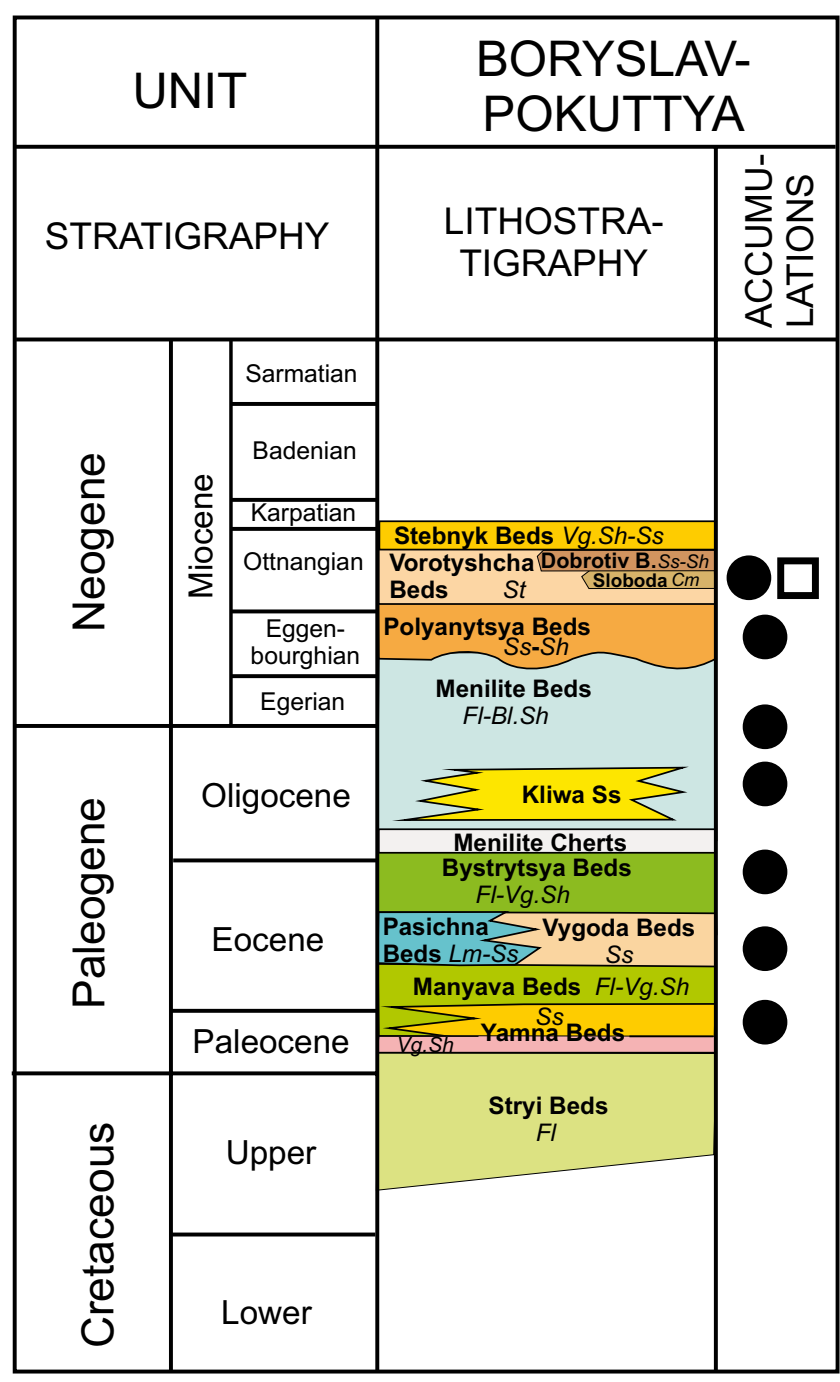

oil and gas condensate fields ozokerite fields

FI - flysch; FI-BI.Sh - flysch with black shales;

$\mathrm{FI-Vg.Sh} \mathrm{-} \mathrm{flysch} \mathrm{with} \mathrm{variegated} \mathrm{shales;} \mathrm{Ss} \mathrm{-} \mathrm{sandstones;}$ Ss-Sh - sandstones and shales intercalations; Lm - limestones; $\mathrm{Cm}$ - conglomerates; St - salt-bearing deposits.

Fig. 5. Generalized lithostratigraphic column of Boryslav-Pokuttya Unit in the Boryslav area, after Koltun et al. (2005) - Zgeneralizowany profil litostratygraficzny jednostki borysławsko-pokuckiej w regionie borysławskim, według Koltuna et al. (2005)

Drohobych - this is the old town famous of salt trade mentioned in historical sources as early as in the 12th century. Salt was produced by evaporation of brines from natural seeps. In the second half of the 14th century (year 1352), when the Halich-Volyn (Red) Ruthenia province was incorporated into the Polish Kingdom by the King Casimirus the Great, the salt industry became the royal domain and salt miners were nominated by the King. It is not surprising that the emblem of this town depicts nine barrels of salt. The oldest district of the town is called "Zwarycka". Its name originates from mining and weighting of salt. In the second half of the 19th century Drohobych was living in the shadow of the great oil town Boryslav but here the infrastructure was situated, working for the for oil industry - distilleries, oil tanks as well as numerous magnificent palaces and ma- 


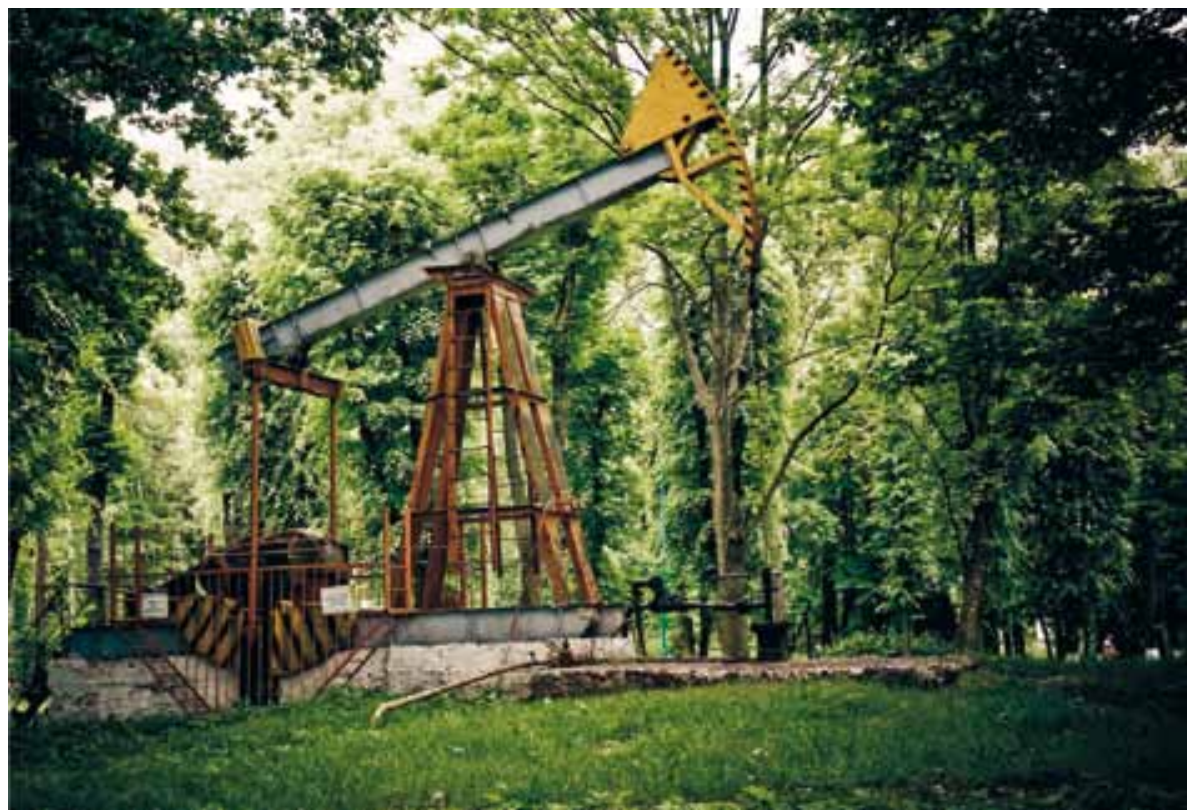

compositions and heal various illnesses (Gąsiorowski, 1935; Strojny et al., 2005). Another value of the health resort is the ozokerite therapy. In the second half of the 20th century extensive research was undertaken on the use of ozokerite for healing purposes. There were also new healing substances invented, known under the commercial names: "Ozokeraphine", "Ozokieraline", "Ozoparafine" and "Ozokerite whey". Ozokerite and its derivatives are still used in external and internal treatments in various stages of trachea and bronchi, mouth and rectum, in anemia of bottom limbs and in prostate problems (Petrowski \& Stecenko, 2001).

The recent Truskavets is a town of huge, multi-storey buildings of

Fig. 6. The active pumpjack located in a municipal park in Boryslav. Photo of M. Czekański • Czynny żuraw pompowy, znajdujący się w parku miejskim w Borysławiu. Fot. M. Czekański

nors of oil barons. Oil traditions are still alive. Between World Wars I and II, two refineries were operating in Drohobych, producing petrol, oil gas, heavy fuel, tar and paraffin. Refineries still exist and are operating. One of them - the "Galicia" was built in 1863 and the second - the "Polmin" - in 1909. Moreover, technical school of oil industry still exists in Drohobych. There are also monuments commemorating the multicultural society of Drohobych. The most precious are: fortified Gothic parish church dated back to the Medieval times, three Orthodox churches - St. Jur, St. Crucifix and The Trinity, the Monastery of Bazylians from 1825 and also ruins of a synagogue from 1842, largest in Galicia (Mściwujewski, 1929; Gąsiorowski, 1935; Strojny et al., 2005; Sikorska et al., 2005, 2006).

Truskavets - this is the largest health resort in the region. Like many other Carpathian heath resorts, it is based on mineral waters genetically related to the oilfields. Beginnings of the health resort in Truskavets are dated back to 1827 , but the period of prosperity was the beginning of the 20th century, thanks to the activity of Teodor Torosiewicz, balneologist, chemist, pharmacist and the chief physician of the health resort. He also significantly contributed to the development of the Iwonicz Zdrój spa. In Poland, between World Wars I and II, Truskavets was the second important Polish health resort after famous Krynica. Its owners - the Jarosz family - looked after its sustained development. At this time a large swimming pool was built for mineral (sulphate) water of temperature $24^{\circ} \mathrm{C}$. Truskavets is famous also of the "Naftusia" - mineral water spring renowned for its healing values (Fig. 10). This low-mineralizated, bicarbonate-calcium-magnesium mineral water with high contents of organic compounds originates from oil deposits and is unique on the world scale. Besides "Naftusia", there are many other mineral water springs in Truskavets: "Maria", "Zofia", "Józia", "Bronisława", "Ferdynand", "Edward" and "Katarzyna". Waters of each spring have different chemical health resorts built after World War II. However, in the centre of the health resort, especially in the neighbourhood of the Boulevard of Torosiewicz, we can still find old boarding houses and villas (Fig. 11), built in Swiss style, commemorating the Polish epoch (Strojny et al., 2005).

Skhidnytsa - locality situated $12 \mathrm{~km}$ from Boryslav, to which a scenic road winds through the Bukhoviy Dil Hills. In the times of Stanisław Szczepanowski, Skhidnytsa was the most effective oil producing centre in Poland (yielding about 17,000 tankers oil per year, i.e., about 170,000 metric tons). The oil well named "Jakub" produced initially about 100,000 long hundredweights of oil per day (one hundredweight $=$ about $50.8 \mathrm{~kg}$ ). Unfortunately, the oil resources were quickly exhausted - between World Wars I and II, Skhidnytsa production dropped down to only 3,000 tankers per year, but was still the third oil producing centre in Poland, after Boryslav and Bytkiv (Jawor, 2004; Michalewicz et al., 2004). Production of petroleum in Skhidnytsa continues to the present and recently we can still find working beam pumps (Gąsiorowski, 1935; Sikorska et al., 2005, 2006). Skhidnytsa is also famous health resort.

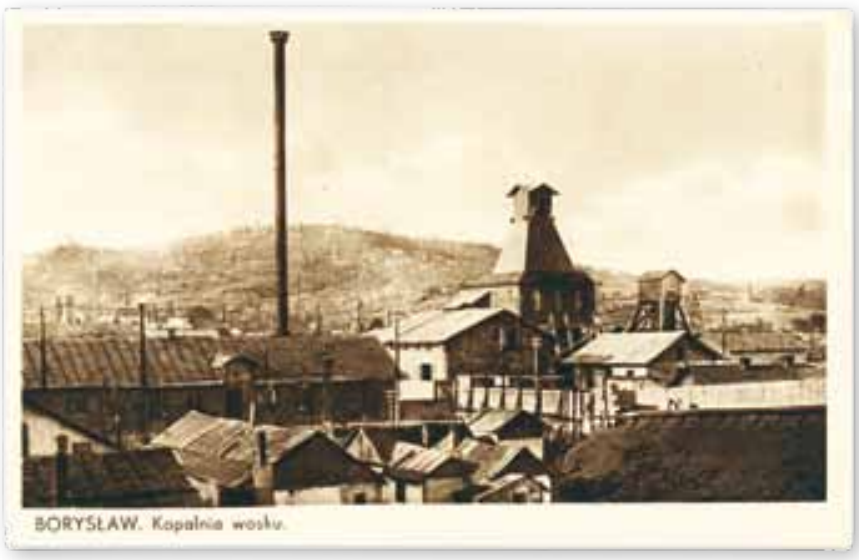

Fig. 7. Ozokerite mine in Boryslav. Postcard edited in $1929 \cdot$ Kopalnia ozokerytu w Borysławiu. Pocztówka wydana w roku 1929 


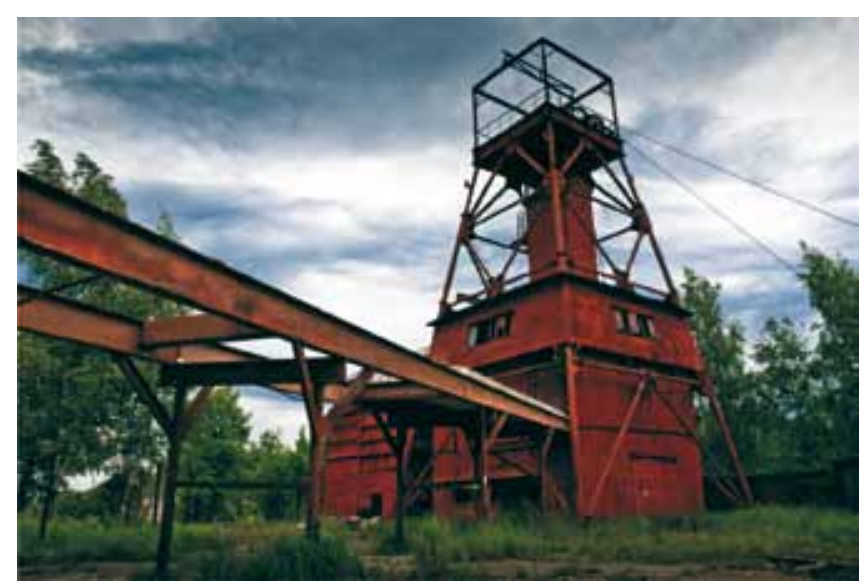

Fig. 8. The last, periodically operating shaft of the ozokerite mine in Borysłav. Photo of M. Czekański • Ostatni, okresowo czynny szyb kopalni ozokerytu w Borysławiu. Fot. M. Czekański

Urych - locality situated $6 \mathrm{~km}$ from Skhidnytsa is famous for beautiful sandstone crags (Fig. 12) and the ruins of the 14th century Tustan Castle. The central group of crags reminds walls and towers of legendary castle (see novel by Zygmunt Kaczkowski entitled "The King's Olbracht Knights") (fide Orłowicz, 1919). The oil wells in Urych produced 40,236 tankers of oil in the years 1895-1928 from 500-metres-deep reservoir in the Jamna Sandstones (Jawor \& Kruczek, 1994). Remains of oil mine are still visible at the road to the ruins of the Tustan Castle. In Urych, Józef Sozański was born - one of the main creators of the Open Air Oil Industry Museum in Bóbrka (Wolwowicz, 2003; Radwański, 2009).

\section{Conclusions}

When traveling through the Boryslav region, the visitors should pay attention to the centuries-old mining activities. Mieczysław Orłowicz (1919) wrote about Boryslav and neighboring Tustanovychi and Volianka villages: "...both localities look like a forest of oil rigs and complex of tanks, among which are situated miserable little houses. These are so dirty and untidy that it is impossible (even in approximation) to find similar ones in the whole of Galicia. There is only one street in Boryslav, Tustanovychi and Volianka, so fields and streams are used for communication. Sidewalks are replaced by boards situated on both sides of the road, which are covered with deep mud for many months. In spite of the fact that during a half century so many people from this country and from abroad have amassed huge fortunes from here, nothing has been done to improve the situation in Boryslav, to provide the residents decent existence, not to mention comforts. This place is rather a camp than an industrial centre, so the worker who comes here seeking jobs tries to earn as much money as possible in a short time and leave this place as soon as possible. Szczepanowski called Boryslav "the hell of Galicia".

Since the 14th century, the salt industry in the area has been declining until the collapse of independent Poland between the years 1772 and 1795. Between the 14th and 18th century most of the Polish salt mines were operating in the
Ukrainian Fore-Carpathian region. Then, in the second half of the 19th century the "oil boom" coincided with the expansion of health resorts based on excellent mineral waters. When a tourist arrives in Drohobych he has a chance to recognize the history of this town, its multicultural character built by successful coexistence of three main nations: Poles, Jews and Ukrainians (Ruthenians) who jointly contributed to the creation of local culture and tradition. On the other hand, he can find out interesting facts about the history of the oil industry flourishing here in the 19th and the 20th centuries with technical monuments, premises of oil companies and banks, residences of "oil barons" and public buildings where people coming from many countries run their businesses.

A very important and interesting aspect of the Boryslav area is the past mining and processing of ozokerite. The worth-seeing site is the Museum of the History of Oil Industry in Boryslav. Tourists can see here the still existing, small shafts from which ozokerite was mined. There is also the last, periodically operating shaft of the ozokerite mine and the processing plant where ozokerite is treated for production of healing agents. This shaft could be also geotouristic site after the reconstruction.

Truskavets situated nearby is nowadays one of the largest health resorts in the Ukraine. There are several reasons why it is worthy to visit this town: (1) it is the historical health resort with beautiful houses built in the Swiss style, reminding times when wealthy patients have visited the resort in the past, (2) there are magnificent mineral springs including the famous "Naftusia", which provide a wide range of therapeutic opportunities, (3) it is a modern health resort complex offering various medical services including the unique ozokerite therapy.

Heading further to the south, tourists can visit Skhidnytsa - health resort with scenic localization in the hills at the road Drohobych - Truskavets - Urych. At the end of the 19th century extremely productive oil wells were discovered and developed in this area. Recently, this is a quickly growing health resort. If time allows, tourist should visit other sites related to petroleum industry heritage, e.g.: Staryi Sambir, Stara Sil, Nakhuyovichi, Opaka and also small health resorts based on excellent mineral waters of the

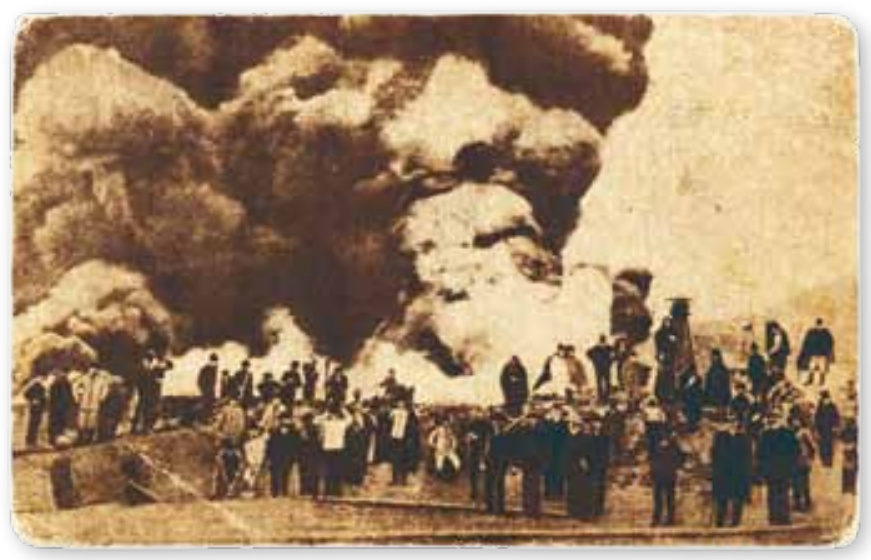

Fig. 9. Fire of "Oil City" oil shaft in 1908. Postcard edited in 1921 • Pożar szybu naftowego "Oil City” w roku 1908. Pocztówka wydana w roku 1921 
"Naftusia" type and others, as e.g. Maidan, Popeli, Modrychi, Yasenytsya Silna, Staryi and Novyi Kropyvnyk, Opaka, Pidbuzh. At all these sites exploration drilling for oil still continues.

Acknowledgements. I would like to thank Prof. Maciej J. Kotarba for his favor, kind attention, suggestions and also recommendations of publications, which enabled me to complete this article. Many thanks are due to Mr. Czesław Bobek, President of the Foundation of The Museum in Bóbrka, for the access to publications necessary to writing the present publication. I would like to thank Mr. Józef Potera - Director of the Department of Geology at the Oil and Gas Company in Sanok, for help in finding one of the publications crucial for this paper. Review comments and suggestions by

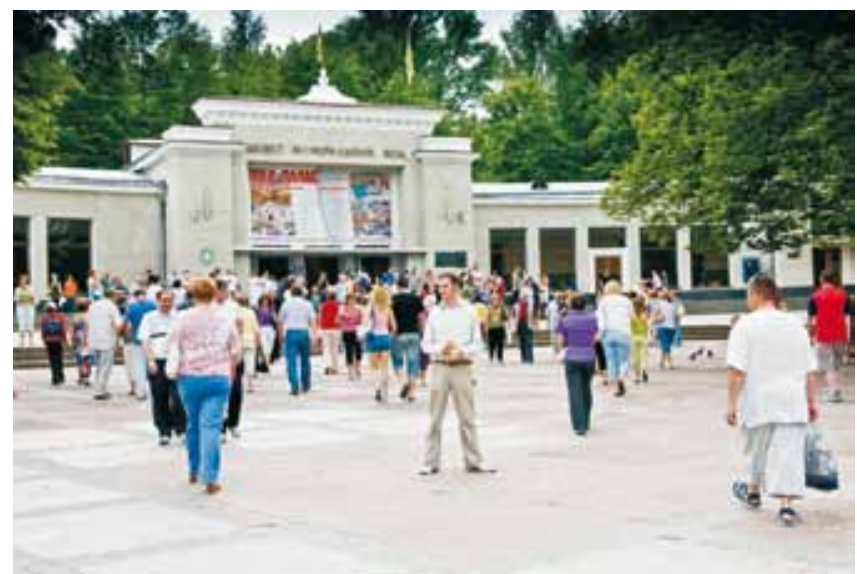

Fig. 10. Truskavets - the old pump room of mineral waters at the Torosiewicz's Boulevard. Photo of A. Radwański - Truskawiec stara pijalnia wód mineralnych przy Bulwarze Torosiewicza. Fot. A. Radwański
Prof. Andrzej Kozłowski of the Warsaw University, Dr. Yuriy V. Koltun of the National Academy of Sciences of Ukraine in Lviv and Dr. Wojciech Mayer of the AGH University of Science and Technology in Kraków were very helpful.

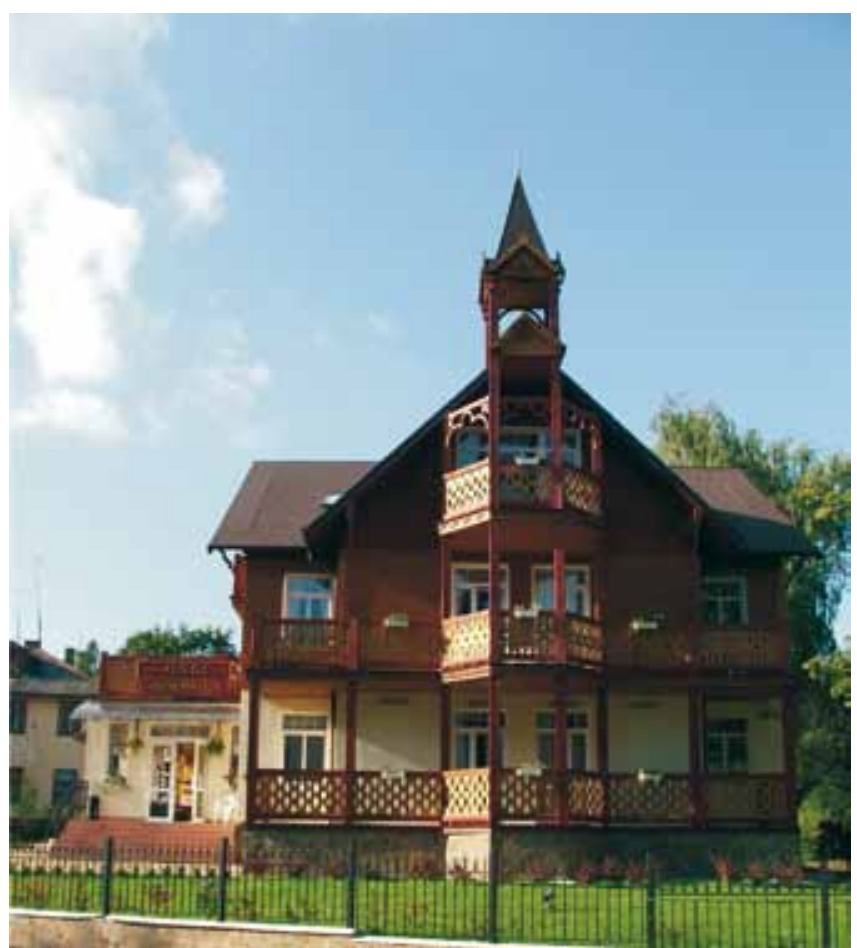

Fig. 11. Truskavets - The Villa "Nabi" (previously "Jagusia") from 1910 on the Taras Schevchenko Street. Photo of A. Radwański • Truskawiec - Willa „Nabi” (dawniej „Jagusia”) z 1910 r. przy ul. Tarasa Szewczenki. Fot. A. Radwański

\section{Krótka historia odkrycia złoża}

Druga połowa XIX wieku to dla Podkarpacia czas gwałtownego rozwoju gospodarczego. „Olej skalny” (ówczesna nazwa ropy naftowej) stał się niemal z dnia na dzień potencjalnym źródłem bogactwa. Działalność wydobywcza objęła tereny od Gorlic na zachodzie po Słobodę Rungurską na wschodzie. Wprowadzenie metody kanadyjskiej wierceń zawdzięcza Podkarpacie osobie Williama MacGarvey'a, Kanadyjczyka, który przybył do Galicji w roku 1883 na zaproszenie pioniera górnictwa naftowego Stanisława Szczepanowskiego, działającego na terenie Słobody Rungurskiej (Jawor \& Kruczek, 1994; Michalewicz et al., 2004; Orłowicz, 1919; Strojny et al., 2005). To właśnie MacGarvey rozpoczął w roku 1893 wiercenia na złożu ropy naftowej w Borysławiu, a w roku 1895 w Tustanowicach. Na terenie Tustanowic znajdowały się najwydajniejsze otwory, np. „Nafta-2” z produkcją 26500 cystern kolejowych $(1$ cysterna $=10 \mathrm{t}) \mathrm{w}$ latach 1907-1935 (Jawor \& Kruczek, 1994). Odkrycie złoża w Borysławiu zapoczątkowało ,złoty wiek” podkarpackiego przemysłu naftowego, a jego odkrywcom przyniosło fortuny (Orłowicz, 1919).

\section{Zarys budowy geologicznej}

Rejon Borysławia położony jest na obszarze występowania trzech karpackich jednostek geologiczno-strukturalnych: skolskiej (krośnieńksiej), borysławsko-pokuckiej i stebnickiej wymarłych ssaków, wosku ziemnego, ropy naftowej i soli" od Staruni na Ukrainie po Kraków w Polsce (Kotarba, 2009). 
(samborskiej) (Fig. 1). Jednostka borysławsko-pokucka jest podstawową megastrukturą roponośną w Karpatach ukraińskich. Tworzy ją zespół ponasuwanych na siebie z SW ku NE, złuskowanych elementów fałdowych, w których uformowały się wielohoryzontowe złoża ropy naftowej. Największym z nich jest Borysław. $Z$ innych ważnych złóż związanych z tą jednostką należy wymienić Bitków-Babcze, Dolina, Rypne, Schodnica, Słoboda Rungurska (Jawor \& Kruczek, 1994; Jawor, 2004; Wyszniakow et al., 2004a, b). Czoło nasunięcia karpackiego w rejonie Borysławia zbudowane jest z czterech skib: skolskiej, orowskiej, brzeżnej i borysławskiej (Tołwiński, 1937), a w skibie orowskiej wyróżniono szereg łusek (Fig. 3). Ciekawostką złoża Borysław są pogrzebane struktury roponośne, przykryte utworami kolejnej, nasuniętej jednostki strukturalnej, w której brak jest przemysłowych akumulacji ropy naftowej (Fig. 4). Skałami zbiornikowymi złoża Borysław w profilu jednostki borysławsko-pokuckiej są piaskowce, które występują od dolnokredowych warstw stryjskich, aż do mioceńskich warstw worotyszczańskich (Fig. 5). W obrębie warstw worotyszczańskich znajdują złoża ozokerytu, w formie żył i pokładów.

\section{Obiekty geoturystyczne}

Dzisiejszy Borysław w niczym nie przypomina tego $\mathrm{z}$ przed lat. Jakkolwiek eksploatacja ropy naftowej trwa nadal (Fig. 6), to jednak w pejzażu nie widać obiektów naftowych jak na starych widokówkach. Jednak od czasów przedwojennych przetrwały jeszcze zbiorniki ropy naftowej. Eksploatacja wosku ziemnego odbywała się metodą górniczą - szybami i szybikami (Fig. 7) (Kachlik, 1994). Zachowany, czynny szyb eksploatacyjny ozokerytu znajduje się w starej części Borysławia (Fig. 8). Pamiątką dawnych czasów jest miejsce w Tustanowicach upamiętniające tragiczny pożar odwiertu „Oil City” w roku 1908 (Fig. 9), kiedy to uderzenie pioruna zainicjowało pożar, którego gaszenie trwało trzy tygodnie (Michalewicz et al., 2004; Orliński et al., 2004).

Drohobycz - to stare miasto, które od najdawniejszych czasów żyło $\mathrm{z}$ handlu solą. Z zapisków wynika, ze prowadzono go już w XII wieku. W 2. połowie XIX w. Drohobycz rozwijał się w cieniu wielkiego, naftowego brata - Borysławia. Pełnił wtedy rolę zaplecza dla przemysłu naftowego, powstawały tutaj pałace i kamienice przemysłowców naftowych. W okresie międzywojennym działały dwie rafinerie ropy naftowej. Jedna z nich - „Galicja” - powstała w roku 1863, a druga - „Polmin” w roku 1909.

Truskawiec - to największe z regionalnych uzdrowisk. Bazuje ono, podobnie jak wiele innych uzdrowisk karpackich, na wodach towarzyszących złożom ropy naftowej. Początki powstania uzdrowiska w Truskawcu sięgają lat 20tych XIX w., ale zasadniczy rozwój nastąpił w początkach XX w. Truskawiec znany jest z „Naftusi” - wody mineralnej o niezwykłych walorach leczniczych (Fig. 10). Innym atrybutem uzdrowiska są kuracje ozokerytowe. Dzisiejszy Truskawiec

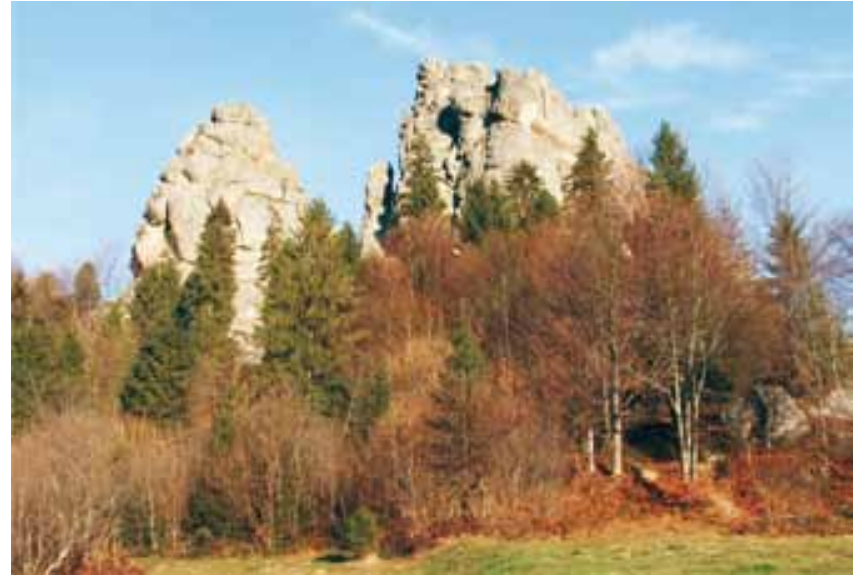

Fig. 12. Rock forms in Urych - the Jamna Sandstones. Photo of A. Radwański • Skały w Uryczu. Piaskowce jamneńskie. Fot. A. Radwański

to miasto ogromnych, wielopiętrowych budynków sanatoryjnych, wzniesionych po II Wojnie Światowej, ale w centrum uzdrowiska, szczególnie w okolicy Bulwaru Torosiewicza, napotkamy nadal stare pensjonaty i wille (Fig. 11) pamiętające czasy polskie (Strojny et al., 2005).

Schodnica-miejscowość oddalona $12 \mathrm{~km}$ od Borysławia. Za czasów Stanisława Szczepanowskiego kopalnia ropy naftowej w Schodnicy była najwydajniejszą w całej Galicji. W okresie międzywojennym produkcja wynosiła 3000 cystern rocznie, co stawiało Schodnicę na trzecim miejscu po Borysławiu i Bitkowie (Jawor, 2004; Michalewicz et al., 2004). Schodnica była też znaną miejscowością uzdrowiskową (Gąsiorowski, 1935; Sikorska et al., 2005, 2006).

Urycz - miejscowość położona w odległości $6 \mathrm{~km}$ od Schodnicy słynna jest z malowniczych skał (Fig. 12) oraz ruin czternastowiecznego zamku Tustań. W Uryczu również znajdowała się kopalnia ropy naftowej (Orłowicz, 1919). Ponadto jest on miejscem urodzenia Józefa Sozańskiego, jednego z głównych twórców Skansenu w Bóbrce (Radwański, 2009).

Poruszając się po regionie borysławskim, zwanym w XIX wieku „Galicyjskim piekłem” (Orłowicz, 1919), należy pamiętać o funkcjonowaniu tu na przestrzeni wieków różnorodnej działalności górniczej. Począwszy od XIV wieku było nią warzelnictwo soli, a następnie, od II połowy XIX w. nastąpił gwałtowny rozwój przemysłu naftowego, któremu towarzyszył rozwój sieci uzdrowisk na bazie wód mineralnych. Jeżeli czas i możliwości pozwalają, można zobaczyć inne miejscowości, związane z ropą naftową: Stary Sambor, Stara Sól, Nahujowice, Opaka, czy dawne małe miejscowości uzdrowiskowe jak: Majdan, Popiele, Modrycz, Jasienica Solna, Kropiwnik Stary i Nowy, Opaka, Podbuż, posiadające wody mineralne typu „Naftusia”. W rejonie tych miejscowości jeszcze dzisiaj prowadzona jest działalność wydobywcza ropy naftowej.

\section{References (Literatura)}

Alexandrowicz, S.W., 2005. The history of "Starunia" - a palaeontologic site and old ozokerite mine. In: Kotarba, M.J. (ed.), Polish and Ukrainian geological studies (2004-2005) at Starunia - the area of discoveries of woolly rhinoceroses. Polish Geological Institute and Society of Research an Environmental Changes "Geosphere", Warszawa-Kraków: 21-38.
Bojko, H. \& Sozański, J., 2004. Ozokeryt. W: Raczkowski, J. \& Zarubin, J. (red.), Nafta i Gaz Podkarpacia - Zarys Historii. Instytut Nafty i Gazu, Wydawnictwo „Naukowa Dumka”, Kraków - Kijów: 345-360. (In Polish and Ukrainian) 
The oil and ozokerite mine in Boryslav and historical monuments of petroleum and salt industries in the vicinity of Boryslav

Bolewski, A. \& Turnau-Morawska, M., 1963. Petrografia. Wydawnictwa Geologiczne, Warszawa, 811 pp. (In Polish only)

Gąsiorowski, H., 1935. Bieszczady. W: Przewodnik po Beskidach Wschodnich. Książnica-Atlas, Lwów-Warszawa, 286 pp. (In Polish only)

Jawor, E., 2004. Historia odkrycia najstarszych złóż ropy i gazu na Podkarpaciu. W: Raczkowski, J. \& Zarubin, J. (red.), Nafta i Gaz Podkarpacia - Zarys Historii. Instytut Nafty i Gazu, Wydawnictwo „Naukowa Dumka”, Kraków - Kijów: 79-90. (In Polish and Ukrainian)

Jawor, E. \& Kruczek J., 1994. Geologia złóż ropy i gazu. W: Wolwowicz, R. (red.), Historia Polskiego Przemysłu Naftowego. Muzeum Regionalne PTTK im. Adama Fastnachta w Brzozowie, Brzozów: 61-131. (In Polish only)

Kachlik, K., 1994. Eksploatacja złóż wosku ziemnego. W: Wolwowicz, R. (red.), Historia Polskiego Przemysłu Naftowego. Muzeum Regionalne PTTK im. Adama Fastnachta w Brzozowie, Brzozów: 296-308. (In Polish only)

Kondracki, J., 1978. Karpaty. Wydawnictwa Szkolne i Pedagogiczne, Warszawa, 273 pp. (In Polish only)

Koltun, Y.V., Adamenko, O.M., Kotarba, M.J., Dudok, I.V., Pavluk, M.I., Burzewski, W. \& Stelmakh, O.R., 2005. Geological setting and petroleum occurrence of the Starunia area, fore-Carpathian region, Ukraine. In: Kotarba, M.J. (ed.), Polish and Ukrainian geological studies (20042005 ) at Starunia - the area of discoveries of woolly rhinoceroses. Polish Geological Institute and Society of Research an Environmental Changes "Geosphere", Warszawa-Kraków: 61-78.

Korin, S.S., 2005. Miocene salt-bearing Vorotyshcha Beds in the Starunia area, fore-Carpathian region, Ukraine. In: Kotarba, M.J. (ed.), Polish and Ukrainian geological studies (2004-2005) at Starunia - the area of discoveries of woolly rhinoceroses. Polish Geological Institute and Society of Research an Environmental Changes "Geosphere", Warszawa-Kraków: 79-86.

Kotarba, M.J., 2009. The Starunia palaeontological site and idea of Ukrainian-Polish trans-border geoturist trail "Traces of large, extinct mammals, earth wax, oil and salt: from Starunia to Kraków”. Geoturystyka, This volume.

Krukar, W., 2004. Carpathian Euroregion, tourist map 1: 765 000. Wydawnictwo Arete II, Krosno.

Lenartowicz, Ś., 1998. Kościół parafialny p.w. św. Barbary w BorysławiuTustanowicach (dawniej Wolanka). W: Ostrowski, J.K. (red.), Materiały do dziejów sztuki sakralnej na ziemiach wschodnich dawnej Rzeczypospolitej. Międzyregionalne Centrum Kultury, Kraków, I/6: 13-18. (In Polish only)

Michalewicz, W.I., Zarubin, J. \& Raczkowski, J., 2004. Historyczne korzenie przemysłu naftowego i gazowego Podkarpacia. W: Raczkowski, J. \& Zarubin, J. (red.), Nafta i Gaz Podkarpacia - Zarys Historii. Instytut Nafty i Gazu, Wydawnictwo „Naukowa Dumka”, Kraków - Kijów: 11-22. (In Polish and Ukrainian)

Mściwujewski, M., 1929. Drohobycz. Wydawnictwo Księgarni Ludowej, Lwów-Drohobycz, 34 pp. (In Polish only)
Nater, R. \& Sozański, J., 2002. Nafta, Ludzie i Fakty. Handel - Usługi Wydawnictwa, Lesko, 197 pp. (In Polish only)

Orliński, R., Jaracz, C. \& Zuzak, J., 2004. Wydobycie ropy na Podkarpaciu w latach 1874-1939. W: Raczkowski, J. \& Zarubin, J. (red.), Nafta i Gaz Podkarpacia - Zarys Historii. Instytut Nafty i Gazu, Wydawnictwo „Naukowa Dumka”, Kraków - Kijów: 212-242. (In Polish and Ukrainian) Orłowicz, M., 1919. Ilustrowany Przewodnik po Galicji. Kwieciński, Lwów, 510 pp. (In Polish only)

Pabis, T., 2003. Władysław Długosz. T. Pabis, Libusza, 35 pp. (In Polish only)

Petrowski, B. \& Stecenko, H., 2001. Truskawiec - uzdrowisko dla wszystkich. SSG „Kurortopolis Truskawiec”, Truskawiec, 19 pp. (In Polish and Ukrainian)

Radwański, A.B., 2009. The Ignacy Łukasiewicz Memorial Museum of Oil and Gas Industry in Bóbrka and historical monuments of petroleum and salt industries in the vicinity of Krosno (the Polish Outer Carpathians) Geoturystyka, This volume.

Rychter, T. \& Teodorczyk, A., 2009. Teoria silników tłokowych. Wydawnictwa Komunikacji i Łączności, Warszawa, 268 pp. (In Polish only)

Sikorska, E., Radwański, A., Roman, S., Ropa, W., Kimak, W. \& Luboniewicz, L., 2005. The Petroleum Trail, International Tourist Trail. Podkarpacka Agencja Informacyjno-Reklamowa, Krosno, 20 pp.

Sikorska, E., Roman, S. \& Kadniczański, A., 2006. Przewodnik po transgranicznych szlakach turystycznych powiat krośnieński - rejon samborski. Starostwo Powiatowe, Krosno, 95 pp. (In Polish only)

Sozański, J. (ed.), 1996. Bóbrka - our petroleum heritage. The Ignacy Łukasiewicz Memorial Museum of Oil Industry in Bóbrka, Krosno, 91 pp. (In English and Polish)

Sozański, J. (red.), 2004. Przemysł Naftowy Podkarpacia na kartach pocztowych. Wiek Nafty, 2-4: 88 pp. (In Polish only)

Strojny, A., Bzowski, K. \& Grossman, A., 2005. Ukraina Zachodnia. Tam szum Prutu, Czeremoszu... . Wydawnictwo Bezdroża, Kraków, 471 pp. (In Polish only)

Tołwiński, K., 1937. Kopalnie nafty i gazów ziemnych w Polsce. Biul. Karp. Inst. Geol.-Naft., Warszawa-Borysław-Lwów, 22. T. II cz. 1, 2. 381 pp. (In Polish only)

Wolwowicz, R., 2003. Mgr inż. Józef Sozański (1932-2003). Wiek Nafty, 4: 23-24. (In Polish only)

Wyszniakow, I.B., Wul, M.J., Dosin, G.D., Ładyżeński, G.M., Pyłypczuk, A.S. \& Swyrydenko, W.G., 2004a. Budowa geologiczna i ropogazonośność. W: Raczkowski, J. \& Zarubin, J. (red.), Nafta i Gaz Podkarpacia - Zarys Historii. Instytut Nafty i Gazu, Wydawnictwo „Naukowa Dumka”, Kraków - Kijów: 33-47. (In Polish and Ukrainian)

Wyszniakow, I.B., Wul, M.J., Dosin, G.D., Ładyżeński, G. M., Pyłypczuk, A. S., Swyrydenko, W.G., Truszkiewicz, R.T., Szpak, P.F. \& Jarosz, B.I., 2004b. Najważniejsze złoża gazu ziemnego i ropy naftowej wschodniego Podkarpacia. W: Raczkowski, J. \& Zarubin, J. (red.), Nafta i Gaz Podkarpacia - Zarys Historii. Instytut Nafty i Gazu, Wydawnictwo „Naukowa Dumka”, Kraków-Kijów: 116-132. (In Polish and Ukrainian)

All the postcards (Figs 2, 7 and 9) are the property of the Museum at Bóbrka • Wszystkie pocztówki (Fig. 2, 7 i 9) są własnością zbiorów Muzeum w Bóbrce 